\title{
Jewish Combatants of the Red Army Confront the Holocaust ${ }^{1}$
}

\author{
Mordechai Altshuler
}

In this essay, I examine how the direct encounter with the results of the Holocaust affected some of the Red Army's Jewish combatants. The focus here is on young Jews who grew up in the Soviet regime and were distant from Jewish religion and culture; I do not deal with Jews from the newly annexed territories, where they continued to lead traditional Jewish lives despite the brief period of Soviet rule.

During the Soviet-German War an estimated 300,000 to 500,000 Jews were drafted into the Red Army. ${ }^{2}$ Some of them were among the liberators of cities and towns that had sizable Jewish populations before the war. For example, one account of liberation comes from a survivor who was a resident of the town of Kryzhopol ${ }^{3}$ in Ukraine's Vinnitsa oblast'. The local Jews were imprisoned in a camp that was surrounded by Romanian guards. A Soviet tank broke into the city and rolled over the barbed-wire fence. One of the soldiers, who was a relative of the survivor, shouted from the tank, "Jews, don't be afraid-you can come out now." These Jewish combatants were the first to come face to face with the aftermath of the Holocaust.

Most of the letters that soldiers sent to their families are short and laconic and do not display any expressions of feelings and thoughts. ${ }^{5}$ Nonetheless, the few testimonies indicate that, for a fair number of Jewish combatants, the direct encounter with the Holocaust, on the one hand, and the eruption of anti-Jewish hatred, on the other, brought about a change in their attitude toward their own ethnic identity.

The father of Iakov Ravich (born in 1925) worked in the Soviet commercial mission in Berlin and was sent to the Gulag in 1937. Iakov lied about his age and volunteered for the Red Army. He wrote his mother the follow- 
ing in a brief letter: "A special portion was allotted to the Jews [in Kursk]. ${ }^{6}$ Hundreds of people were taken and put aboard trucks and gas cars [dushegubki]. They were transported to an area outside the city and none of them ever came back." 7

Vulf Zelenyi expressed his empathy with the Jewish people in a typically Soviet fashion. Born in 1923 in Kharkov, he was evacuated to the city of Molotov (Perm') together with the factory in which he was employed. In 1942, he joined the Red Army and was sent to the front. He participated in the heavy fighting at Stalingrad, from where he wrote to his mother on February 20, 1943:

This is a difficult hour for many nationalities of the Soviet nation, especially for the Jewish people. Hitler's bloody hands want to subjugate the Jews and, what is even worse, to wipe them off the face of the earth. However, that goal will never be achieved. The Jewish people will show him [Hitler] where true justice lies and will revenge the torture its sons and daughters have endured. Knowing all this, I am fighting the enemy courageously and heroically as a member of the Jewish people. ${ }^{8}$

For reasons of field security, Red Army soldiers were not permitted to keep diaries; however, this prohibition did not apply to poets and writers, who were allowed to express their feelings even while participating in the fighting. This is the case with two poems written by a Russian poet of Jewish descent, Iakov Khelemskii (born in 1914), who was one of the liberators of the Latvian capital. In the course of a few days, he wrote two poems, both entitled "Riga."' In the first poem, he describes the city's buildings with their northern European architectural style. Young girls with flowers greet the liberators: "They are running toward them with daisies in their hands/ They are running quickly, they are in a hurry, these girls with their multi-colored kerchiefs." The festive mood changes quickly when the poet turns toward the northern part of the city, where he feels:

The dying ghetto...

the Jewish quarter is cut off with barbed wire...

Behind every door a human being once lived...

Here they lived, loved and hated

Here they prayed to God... 
Here there is a smell of blood and of cruel pain.

Here each stone dies after being tortured.

Here every house becomes another Wailing Wall....

This sorrow cries out with all the power of their muteness...

and the searing heat of the tormented ghetto

you can feel with the skin of your body.

In the first poem, the city comes to life, whereas in the ghetto there is nothing but death and a heap of rubble. The poet hears and senses through the pores of his skin-physically-the mute cries of the murdered victims. The contrast between the unique fate of the Jews and the surrounding society is thus given emphasis. Vasilii Grossman expressed a similar feeling in a letter to his wife in early 1944 :

Yesterday I was in Kiev. It's hard to express what I felt and what I suffered in the few hours when I visited the addresses of relatives and acquaintances. There are only graves and death. I am going to Berdichev ${ }^{10}$ today. My comrades have already been there. They said that the city is completely devastated, and only a few people, maybe a dozen out of many thousands, tens of thousands, of Jews who lived there, have survived. I have no hope of finding Mama alive. The only thing I am hoping for is to find out about her last days and her death. ${ }^{11}$

Although combatants were prohibited from taking notes, some of them clandestinely recorded their thoughts and impressions. One of those was Moisei Loifer, who wrote down anything that he considered important. Loifer was born in the town of Kanev in Ukraine. ${ }^{12}$ The language spoken in his home was Yiddish, and his father was one of the organizers of a kolkhoz in the late 1920s. Although the family observed the Jewish holidays, Moisei openly demonstrated his negative attitude toward religion, even eating in public on the fast of Yom Kippur. He was drafted in 1939 and remained in uniform until the end of the war. In September 1943, his unit set up camp in the vicinity of Smolensk, ${ }^{13}$ and the villagers in the area related how the Germans "gathered about 100 people from families that had members in the partisan groups, and that included Jews who had sought refuge in the forests.... Gasoline was poured on them and lit torches were thrown at them. 
The people were burned to death."14 Between December 13 and 17, 1943, he recorded the following in his diary:

Along the way, we learned that, in an anti-tank ditch, in the town of Liady ${ }^{15}$... the Germans collected about 3,000 Jews, who were residents of Liady and surrounding towns. The Germans "ironed" them in the ditch with the tanks; afterwards, they covered up [the ditch]. For several days, the earth in the ditch was in constant motion and you could hear groans. ${ }^{16}$

One of the few soldiers who made almost daily entries in a diary during the fighting, Gedalia Safian, ${ }^{17}$ recorded on July 18, 1944:

The first small town on the [now former] trans-Soviet-Polish border was Witkow Nowy. ${ }^{18}$ The center of the town had been burned down. On one house two Stars of David had been painted ... [W]hite shells [of houses], without windows or doors, were still standing. Once there was life in those homes, happy and sad occasions took place there. Where are those people now? How hard it must have been for them in the last days [of their lives]. ${ }^{19}$

A few days later, in the provincial capital of Radziechow, a festive rally was held to mark the town's liberation and ardent speeches were made from the podium; however, Safian visualized something entirely different:

A strong breeze passing through the square was playing with the pages of ancient Jewish books that were being used to wrap cherries in the market. The letters of the ancient Aramaic language were shining brightly and it was so difficult to look at them. They had been looted from the houses along with the other possessions of the town's shoemakers, tailors, shopkeepers, the luftmentshn [people with no definite income] and the synagogues-people fanatically attached to their religion once lived in this town. They were annihilated and the ruins of their homes and the pages of holy books are the sole reminders that they ever existed. ${ }^{20}$

This same kind of deep emotional attachment to the "worn-out Hebrew letters," which many of these young Jewish soldiers had previously regarded 
with disrespect and scorn, can be seen in following passage from a letter written by a Jewish combatant to Il'ia Ehrenburg in 1945:

The bloodthirsty looters shot to death 44 of my relatives, including my sisters and my parents. The members of my brother's family were buried alive.... I have passed through nearly all of Estonia, Lithuania and Poland without meeting a single Jew.... A short while ago, we took up a lookout position in the attic of a house in a Polish town that we had recently liberated. In this attic I found many Jewish books, which seemed to be weeping over the fate of their owners.... I am not religious but, when I held a Passover Haggadah in my hands, I began to weep. ${ }^{21}$

The Hebrew letters that many of the young Jewish soldiers had previously considered as representatives of the world of yesterday now acquired a new significance in their eyes and some of these soldiers tried to learn them in the frontline trenches. In 1943, Samuel Margolin was inducted into the Red Army. He was the grandson of Shraga-Feivel Margolin (18701942), the publisher of the Hebrew-language newspaper Hazman, which appeared in Vilna in 1910. In Samuel's last letter to his mother, which he wrote on September 14, 1943, he asked her, "Please send me the Jewish alphabet." However, before the 18-year-old soldier could begin learning this alphabet, he fell in battle in a village in the Smolensk district in early December 1943. ${ }^{22}$

Ber Mark (1908-1966), a Jewish historian from Poland who was at that time in the Soviet Union, detected this change in the attitude of Soviet Jewish soldiers toward the Hebrew alphabet and devoted an entire (semi-) documentary story (ocherk) to this topic, entitled "The Square Letters." He opens his story with the description of a chance meeting with a Red Army soldier in a railroad station close to the front. A wounded soldier, who did not look at all Jewish, got off the train at this station. However, when the soldier saw Mark holding a book written in "square Hebrew letters," he approached the narrator and introduced himself as a Mountain Jew. A friendship developed between Mark and the soldier, and Mark would regularly visit his new friend in hospital. During one of their meetings, the soldier told the narrator about the liberation of a town in which he discovered great suffering and destruction. When he asked "And where are the Jews?," he was 
taken to a place outside the town, where he saw scorched corpses. Beside the corpses,

There was the scorched corpse of a child that was so full of holes it looked like a sieve. The boy was holding a book. A simple book that had been printed in square Hebrew letters was lying open on the ground. The book was slightly soiled by the mud and somewhat scorched.... [The soldier] picked up the book.... On one of the pages there was a large yellowing bloodstain.... Had the child opened the book at this page when he received the initial deadly blow from his murderer? [The soldier] tore out the page and kept it. Whenever no one was looking, he would take it out of his pocket, smooth it out and look at the yellowing print and the mute letters. ${ }^{23}$

The soldier recovered and continued to fight against the Germans with admirable courage in the Caucasus Mountains. In one of those battles, he was fatally wounded and the narrator one day received a letter from a hospital. The letter was accompanied by a "page from a Jewish book. There was a stain in the middle of the page. 'Guard this, my dear friend, in case I die.... This page is printed in those beloved square letters and has been sanctified by the blood of a holy child." 24

Mark deliberately chose a Caucasus Mountain Jew as the hero of his tale. The language of these Jews had not been written in the letters of the Hebrew alphabet since the $1920 s ;{ }^{25}$ thus, Mark was alluding to the hundreds of thousands of Jewish soldiers in the Red Army who knew Russian but had no knowledge whatsoever of the Hebrew alphabet. Not only did the letters of the Hebrew alphabet draw Jews closer together during the Second World War, the letters acquired new significance because they became a symbol of the blood of the Jews murdered by the Nazis. Thus, the hero of Mark's story preserves a Hebrew text although he is unfamiliar with the language; moreover, the letters in that text are regarded here as holy.

The Soviet education system as well as Soviet propaganda continually stressed that there was no such entity as a Jewish nation, and that there never was and never could be a common destiny linking Soviet Jews who were engaged in building a socialist world with the Jews of capitalist countries. Many young Soviet Jews accepted this approach and even adhered to it with fervent conviction. This attitude of the Soviet Union did not change during World 
War 2, even if for propagandistic and practical reasons they organized the Jewish Anti-Fascist Committee. However, when Jewish combatants of the Red Army came in direct contact with the results of the Holocaust, the emotional impact seriously undermined this belief, at least at the subconscious level.

In his memoirs, Anatolii Rybakov (1911-1998), who would later become a well-known Russian writer, describes his encounter with a Holocaust survivor whom he met in Berlin in the course of his duties as a Red Army officer:

On the first day [of my stay in this city] I noticed a thin woman in a courtyard.... [H]er dress, coat and kerchief were all black. She stared at me intensely and then, in the evening, she was again standing in the courtyard and staring at me. The next day, she approached me and, with considerable hesitation, handed me a small piece of paper on which a Magen David (Star of David) had been drawn. It was obvious that she was Jewish, that she had been hiding and that, when the Russians came, she had decided to "expose herself" [that is, expose her Jewishness] to a Soviet Jewish officer... [At headquarters, where the author of this memoir took the woman] she removed the kerchief from her head: Half of her hair was black, and the other half was white.... Here was a totally exhausted woman who was probably 35 or 40 years of age; yet she already looked like an old woman .... When she revealed her age, my tongue clicked against my palate-she was actually only 16 years old! ${ }^{26}$

The Star of David-which, in caricatures and newspaper articles in the Soviet Union, was used to symbolize Jews in the capitalist world who, according to Soviet ideology, were so distant from the Jews of the USSR-now became a sign that led this Jewish Red Army officer to feel a kinship with a young Jewish girl from Germany whose language he did not even know.

The sense of solidarity that Soviet Jewish veterans felt toward Jews of other countries was expressed in various ways. Evgenii Khaldei (1917-1997) served as a military photographer, and his staged photograph depicting Red Army soldiers hanging the Soviet flag on the Reichstag became a symbol of the USSR's victory over Nazi Germany. Many years after the war, he described his chance meeting with a Jewish pilot serving in the U.S. Air Force. The military unit to which Khaldei was attached was in Romania at the time. When they sat down to eat, a rumor spread that an American bomber had been downed 
and its pilots had survived the crash. Suddenly, the Red Army soldiers saw the American pilots led by their commander walking toward them: "I was sitting beside my friend Grinia. I turned to Grinia and said to him, 'you see the captain over there?... I think he's Jewish." After the two Soviet soldiers had wagered as to the captain's Jewishness, Khaldei turned to the officer, asking him in Yiddish, "Du bist a yid?" (“Are you Jewish?"). Khaldei recalled:

The officer jumped to his feet and gave me a big hug. I gave him a present: a hundred-ruble note with Lenin's picture on it. [To reciprocate, the Jewish officer gave Khaldei a ten-dollar bill and] wrote on it something from right to left.... I told him, "I can speak Yiddish, but I can't read Yiddish. What did you write?" He replied, “There is no place on earth where two Jews cannot find one another."27

In January 1945, the photographer reached Buda; the Germans still controlled Pest. Like all military photographers, Khaldei's job was to document the heroism of the victorious Red Army. However, when Khaldei saw an older Jewish couple wearing yellow Stars of David on their jacket lapels, he decided to record this fact. The photograph was never circulated in the USSR. In an interview, he described the situation in which he took that photo:

I saw them walking down the street. I was in a black leather coat, and at first, they were afraid-they thought I was from the SS. I walked over and tore off their stars, first the woman's, then the man's. She got even more frightened. She said, "No, no, you can't do that, we have to wear them!" I told them that the Russians were here. I told them, "Ikh bin oykh a yid. Sholem aleykhem" (I'm Jewish too. Hello). Then she cried. $^{28}$

Having grown up in a village in an area populated by Cossacks in the Taganrog district, Khaldei apparently had had no Jewish education except for a few Yiddish words he had picked up from the grandfather who raised him. Nonetheless, he was very moved by the encounter with the American Jewish soldier and by the words the latter had written on the ten-dollar bill; similarly, Khaldei reacted very emotionally when he was confronted with the yellow Star of David, which symbolized the Holocaust in which his father and three sisters had been murdered. 
A similar, spontaneous emotional reaction was evident among the Jewish soldiers who liberated a village near Uman' ${ }^{29}$ and who encountered a little Jewish girl there who said to them in Yiddish, "Don't forget what you have seen here with your own eyes." ${ }^{30}$ Such expressions led the Jewish Red Army combatants to identify with the Jews they encountered and to sense the existence of a common Jewish destiny, just as was the case in the next example describing an encounter in the streets of Berlin after Germany's defeat.

After Germany's surrender, groups of Red Army soldiers wandered through Berlin's streets, where smoke was still rising from the ruins of some of the destroyed buildings. The soldiers sang and felt jubilant. When the Jews among them encountered Jewish soldiers from the Polish Army conversing in Yiddish, they left their comrades, and joined the Polish Jews. David Kahana, the rabbi of the Polish Army, testified about the atmosphere of the meeting as follows: "We mingled among them-and they drank a toast with us, shouting out "L'chaim." A few minutes later, you could have sworn that all the persons standing there, beside Berlin's Brandenburg Gate, were old friends, even relatives, members of one large family. ${ }^{31}$

The change in attitude toward Jewish symbols and feelings of solidarity with Jews who had survived the Holocaust were sometimes expressed in letters by Soviet Jewish combatants that were sent to their relatives in ways that bypassed military censorship. The text of one such letter, which was received in Tashkent in October 1944, was included in a published book of memoirs. The mother of a Jewish combatant was very worried after not hearing any word from her son, who was on the front for two months. She finally received a letter from him. Her son wrote that, two months earlier, he had been wounded in battle in the town of Ponovich. Since the hospitals were full, those soldiers whose wounds were not serious were billeted in private homes. The soldier was happy to report that he was on his way to a full recovery. He wanted to do more than just dispel his mother's worries and therefore shared some of his feelings with her:

I was lying on my bed...when I spied a small object affixed to one of the doorposts. It was a narrow rectangular box.... I had never asked before what it symbolized.... This time I asked the homeowner and her reply was: "This is not a cross, but rather it is a Jewish amulet.... In our communities, this amulet did not save the Jew-boys. We finished them off with some small measure of assistance from the Germans.... 
You must not pay attention to the traces that they have left here and there and which still emit a foul Jewish odor. Take it easy, we scoured the house thoroughly before we moved in." My blood boiled inside me! This is a mezuzah and I do not even know what it contains. Yet it has become a symbol for me, a symbol of my nation's suffering! ${ }^{32}$

He closes his letter with the following words: "My dearest mother, when I married Nadia [who was apparently not Jewish], you asked whether I would remain loyal to my Jewish origins.... Today more than ever, I am yours and I know precisely to whom I belong." 33

Whenever Soviet Jewish soldiers participated in the liberation of a city or town where they or their relatives had lived before the war, they sought out relatives who had survived the Holocaust. One Jewish soldier, who reached Kiev soon after its liberation, noted:

There was not even one Jew left here.... I stopped an old man on the sidewalk and asked him what life had been like here under the Germans. "My son!" he cried out, "We lived, we served, because they were the ones who were in control." I asked him, "But where are all the Jews?" The old man closed one eye and looked at me with surprise. "What, you mean, you don't know?!" he sounded incredulous. "All those who didn't manage to flee-were murdered at Babii Iar.... Our strong young fellows worked hard to please the Germans." I just left the old man standing there and started to run.... I ran so that I wouldn't have to see anything or hear anything. ${ }^{34}$

Another Jewish combatant who reached Kiev, ${ }^{35}$ where he had lived before the war, wrote to his family back home, "I returned to Kiev on November 6, 1943 [the day the city was liberated].... I was in Kreshchatik, ${ }^{36}$ which lay in ruins, and, at 11 in the morning, at Babii Iar and the Luk'ianovka cemetery." In his letter, he noted that he simply did not have the strength to describe what he had seen with his own eyes; however, he stressed that the images he viewed would remain with him until his dying day. ${ }^{37}$ Another Jewish combatant $^{38}$ returned to his hometown of Mariupol' ${ }^{39}$ soon after its liberation, where:

[He] learned that his entire family-his wife, his two children, and another 96 relatives-were [all murdered].... He went to see acquaintances and neighbors to learn what had happened to his 
relatives and, in every apartment, he recognized their possessions: in one apartment, there was a clothes closet, in another a few chairs, and, in a third, one of his wife's dresses.... He could not bring himself to ask that these possessions be returned to him because they conjured up memories of the past, but that was the very last time he ever visited those neighbors. ${ }^{40}$

Quite a number of Jewish combatants who were granted an early discharge from the Red Army due to injuries hastened to return to their hometown or the hometowns of their relatives. These soldiers came into direct contact with their own personal tragedies and those of their families. One such combatant had escaped from a prisoner of war camp, joined the partisans, and ultimately fought as a member of the Red Army. Many years later, he wrote, "After my discharge from the army, I returned to my home in Cherkassy. ${ }^{41}$ In every single [Jewish] family there, at least one member had perished. Of the 32 members of my own family, 16 had been murdered." 42 It is not too difficult to imagine the feelings and thoughts of Jewish combatants in such situations; however, it can be stated with a high degree of certainty that a wide gap developed between them and the neighbors with whom and in whose company they had spent time up until the war.

Several Jewish soldiers who were unable to reach their hometowns tried to discover the fate of their relatives through letters to other family members as well as to friends and acquaintances. One of those who corresponded with relatives in the quest for information was Major Moisei Shvartsman, ${ }^{43}$ who, on July 22, 1944, posthumously received the Hero of the Soviet Union medal for bravery in battle. Born in 1911, he spent his childhood and adolescence in a village where there were very few Jewish families. ${ }^{44}$ From an early age, Moisei was involved in political activity in his village and, in the early 1930s, he was sent to a pedagogical college in the provincial city of Vinnitsa. After his graduation in 1936, he returned to the district town not far from the village where he was born-Tyvrov-and, as an active member of Komsomol (the Communist youth movement), he was appointed director of the education department. After the German invasion of the Soviet Union, all members of Komsomol were called upon to join in the defense of the homeland. Moisei was conscripted on June 25, 1941, and he said goodbye to his wife Hannah (Nusia), his daughter Dusia, and his parents. Fighting in the battles that were waged in Smolensk, Moscow, and other parts of the Soviet Union, he had no 
knowledge of his family's fate. After considerable effort, he found his wife and father, both of whom had managed to flee to Kazakhstan; his daughter and his mother remained under the Nazi occupiers. On June 2, 1944, his wife informed him that the Nazis had murdered his daughter and mother. He then wrote the following to his brother:

I saw entire towns and district centers where all the Jews, all of them, had been shot-not one Jew survived. When I read about the massacres in Kiev, Kharkov, and other cities in Ukraine, I began to have doubts whether either of our parents...were still alive.... I will remember June 2, 1944 for the rest of my life, because, on that day, I learned of the fate of our parent and relatives ... in short, I learned of the fate of Dusia and my mother. ${ }^{45}$

However, Moisei did not live a long life. On June 25, 1944, he headed a unit that established a fortification on the banks of the Western Dvina River in the Vitebsk region, and he fell in the battle that took place there.

Leon Shmerkovich, who served as a sergeant in the reserve battalion of the First Ukrainian Front, turned to neighbors soon after the liberation of Kharkov on February 16, 1943 in order to find out the fate of his parents. Leon and his sister were evacuated from Kharkov together with the employees of an engine factory, Serp $i$ molot, where the sister worked. Their parents remained in their hometown. A few months later, he received a reply in which one of the neighbors described the mass murder of the Jews in this city. "The letter I received was read by all the soldiers in our battery," recalled Shmerkovich, and one of them wrote a poem about this letter, which included the following passages: "A father and mother stand beside the ditch/ And beside them stand thousands of Jews,/ Rows and rows of Jewish families." ${ }^{\prime 6}$ Until his dying day, Shmerkovich preserved the letter and the poem, both of which he regarded as a monument to the memory of his parents' last moments.

A few years later, a career officer in the armored corps, Yosef Nudelman, wrote the following:

In 1944, when I learned that the cities of Zhitomir and NovogradVolynkii had been liberated, I immediately sent a query to Chervonoarmeisk, where my family had lived prior to the war.... The 
fate of the family was clear from what had been written on a small piece of paper: "Your family perished at the hands of the fascist German occupiers." I was not at all surprised when I received that reply, although I cried all night just like a little child. ${ }^{47}$

Another Jewish combatant, a resident of the city of Nikolaev ${ }^{48}$ which was liberated in late March 1944, turned to a close friend, who informed him that his parents and brother had been murdered between September 15 and 17, 1941. In the correspondence between the two, she described the lives of her family and their return to a normal routine in Nikolaev. ${ }^{49}$ Furthermore, in this correspondence, in which the friend emphasizes that she is still unmarried, one can easily distinguish the gap between, on the one hand, this Jewish soldier's loneliness and his situation as an orphan and, on the other, the life of his friend and her family.

One Jewish soldier who volunteered to serve in the army soon after the German invasion of the Soviet Union and who experienced all the hardships of the retreat, the city's encirclement, and the battle, wrote many years later: "I cried on more than one occasion. I remembered my mother, my father, my grandfather and my grandmother." ${ }^{50}$ This same orphaned feeling is expressed in a letter written by a Jewish combatant who learned that all the members of his family had been murdered (apparently in Breslav and its environs). The letter ends, "Why I am even writing to you? After all, you are strangers! [...] This is a hard time for me and I must share everything I feel with someone-I have no one who is close to me, you must understand me!"51 In a letter written on July 3, 1943 to the father of a friend who fell in battle, Boris Schwartzman, another combatant, concluded, "Two years have passed since I lost my family.... I once lived in Odessa. My father, my wife and my son, who would be now nine years old-I have lost everyone and now I have no one." 52

This feeling of orphanhood, which was common among many Jewish combatants in the Red Army, stood in sharp contrast to the expressions of antisemitism they experienced from local residents and sometimes even among their own comrades. Concerning antisemitic incidents in the ranks of the army, it seems that a significant difference existed between the initial and the final years of the Soviet-German war. In the early period, Jewish soldiers apparently did not encounter crude expressions of antisemitism, even when they heard certain jokes that made them feel uncomfortable. ${ }^{53}$ Such 
allusions were described in the autobiographical novel of the unrecognized Russian writer and poet ${ }^{54}$ of Jewish descent, Aleksandr Sobolev (1915-1986). His novel Yefim Segal: A Sergeant Who Suffered Shell-Shock, first published in 1999, is based on the writer's experience in the army. Sobolev was conscripted in 1942 and served until his discharge in late May 1944 due to a serious physical injury and to his shell-shock. Describing the atmosphere in his military unit, he wrote:

When the soldiers in the company where Yefim [that is, the author] learned that he was Jewish, they cried out, "But that's impossible! How can Segal be Jewish? Segal, you are a brave fellow, a machinegunner, and you even went out on reconnaissance missions [behind enemy lines]. No, Jews don't act like that! They are all in hiding back home, and besides, your surname isn't Haimovich, Rabinovich or Abramovich. OK, so what if you have curly hair? A lot of us Russians have curly hair, too. Stop slandering yourself, you're not Jewish!" Yefim tensed up when he heard the mocking, scornful and disgusting tone with which they pronounced the names Haimovich, Rabinovich and Abramovich. ${ }^{55}$

The traditional Jewish stereotype was deeply rooted in the public's awareness and it was expressed in the ranks of the Red Army as well.

However, the situation changed as the war progressed. As the Red Army achieved victory after victory on the battlefield, feelings of chauvinism intensified among the Slavic peoples and found expression in the ranks of the Red Army as well. An additional factor was at play here. Whenever a place was liberated from Nazi occupation, its young people were inducted into the Red Army. These young people had been fed with widespread antisemitic propaganda; they had been witnesses to the mass murder of Jews and some of them may even have been indirect collaborators in that murder. Boris Potik (born in 1914) was one of the soldiers who liberated Kharkov. After bitter fighting, the soldiers of Potik's unit were sent to one of the villages to relax. While they sat together in one of the houses in the village, the farmer who lived there said, "Jewboys [zhidy] aren't fighters!" "This was the first time in my entire military career that I had ever encountered antisemitism," admitted Potik. His comrades-in-arms reacted sharply to the farmer's words and threw him out the window. ${ }^{56}$ 
Apparently, the increasing frequency of antisemitic outbursts in the ranks of the Red Army troubled Il'ia Ehrenburg, who was very sensitive to any expression of antisemitism. He raised the issue publicly, albeit indirectly, in the second general assembly of the Jewish Anti-Fascist Committee, which convened from February 18-20, 1943. In his unique, sophisticated way, Ehrenburg did not refer directly to antisemitic incidents in the army but instead called attention to their occurrence on the home front, and the resulting infiltration of antisemitism into the ranks of the Red Army. Furthermore, he noted the disastrous effect that this antisemitism was having on the fighting capacity of the Red Army:

Many [of the soldiers] on the frontlines are not even aware that they are Jews. They have, however, begun to sense their Jewishness after receiving letters from relatives in Uzbekistan or Kazakhstan. In these letters they read, "Here people are saying that they don't see Jews on the front, that the Jews aren't fighters." When they [the Jewish soldiers] receive such messages, while they sit in trenches or while they are on the move, their peace of mind is disturbed.... In order to ensure that Jewish soldiers and commanders in the Red Army can fulfill their duties, we must report how Jews are fighting on the front. ${ }^{57}$

Anti-Jewish hatred in the ranks of the army was also expressed in private letters. For instance, one soldier on the Stalingrad front, who apparently was a prisoner in the Gulag before his induction into the army, wrote the following:

It's really too bad that people are being killed because of the parasites and their control of the Russian people on whose bones socialism was built. These bones are now loudly sighing.... However, that is not enough for a [Russian] man, who has to be [beaten] again and again so that he will become meaner and will wake up to the fact that the Jews are very smart, very vicious, but also silent and very crafty parasites that shouldn't be allowed to gain entry anywhere.... We are all sick of moving around from place to place and fighting for a bunch of Jews. ${ }^{58}$

One Jewish combatant described a particularly crude antisemitic incident in the Red Army many years later. The incident took place during one of the bloodiest battles in the Zhitomir-Berdichev campaign (December 24, 1943-January 14, 1944). After several days of continued fighting, the soldier 
tried to get some sleep. He was rudely awakened by the shouts of the battalion commander, Labazov: "Why aren't you reporting? I forbid any of my soldiers to sleep while a war is going on! You'd better watch your step around me, Jew-boy face [zhidovskaia morda]. This isn't your Palestine!'... I lost my selfcomposure and drew my pistol." ${ }^{59}$ The Jewish soldier was punished for his reaction. However, the incident hurt him very much, as can be seen from the fact that, although the event took place many years earlier, he was able to describe it so precisely. In his diary, Gedalia Safian also recorded in early January 1945, "Sometimes I hear such crudely mocking antisemitic remarks." ${ }^{60}$ These blatant antisemitic incidents, which took place even in the army, only served to intensify the sense of solidarity that the Red Army's Jewish combatants felt toward their coreligionists.

Of course, one cannot speak of a standard response to the Holocaust among the hundreds of thousands of Jewish combatants who served in the Red Army during the Soviet-German war. Many of them considered the massacre of Jews to be just one more expression of the atrocities of the occupiers. ${ }^{61}$ However, there were also many cases where the direct encounter with the unique fate of the Jews during the Holocaust, combined with the hostility of their comrades-in-arms, produced among Jewish combatants a changewhether short- or long-term-in their attitude toward their Jewish ethnicity and its symbols and had a profound impact on their identity.

\section{Notes}

1 This article is part of a comprehensive research study, "The Impact of the Holocaust on the Ethnic Awareness of the Jews of the Soviet Union," which is being supported by the Israel Science Foundation (650/05).

2 No serious demographic study has yet been conducted on the number of Jews inducted into the Red Army during the Soviet-German War of 1941-1945. Most of the publications refer to 500,000 Jews, relying directly or indirectly on Jacob Kantor's article in a Polish Yiddish-language newspaper, "Yidn oyf dem grestn un vikhtikstn front," Folks-Shtime, 18 April 1963, 8-11. Kantor's article is flawed for the following reasons: (1) He uses Soviet declarations concerning the number of inductees in the Red Army during this war and, basing his conclusion on the percentage of Jews in the general population, arrives at the figure of about half a million; (2) he does not take into account the division between the sexes, which was different among the Jews and in the general population (women were not drafted); (3) he overlooks the different age 
breakdown among the Jews and the general population; and (4) he fails to deal with the problem that, in a large number of the cities and towns that were captured in the first weeks of the war, almost no residents were conscripted.

On the eve of the war, Jews constituted more than one-third (37 percent) of the town's general population; see Mordechai Altshuler, ed., Distribution of the Jewish Population of the USSR, 1939 (Jerusalem: Hebrew University of Jerusalem, Centre for Research and Documentation of East-European Jewry, 1993), 23.

4 Interview with Devorah Shaikovich (Lamdeman), born in 1925, which was conducted on June 20, 1989, Yad Vashem Archives, 03/5459, 18.

5 See, for example, Ilia Al'tman and Leonid Terushkin, eds., Sokhrani moi pis'ma.... sbornik pisem i dnevnikov evreev perioda Velikoi Otechestvennoi Voiny (Moscow: Tsentr i Fond "Kholokost": Izd-vo "MIK”, 2007).

6 According to a 1939 census, there were 4,914 Jews living at the time in Kursk; they constituted 4.1 percent of the city's general population (Altshuler, Distribution of the Jewish Population, 35).

$7 \quad \mathrm{Al}^{\prime}$ tman and Terushkin, Sokhrani moi pis'ma, 231.

8 Ibid., 287.

9 Iakov Khelemskii, “Riga,” Znamia (1945): 51-52.

10 On the eve of the war, there were 23,300 Jews in Berdichev, or more than a third (37.5 percent) of the city's population (see Altshuler, Distribution of the Jewish Population, 22). Concerning the general population's feelings about the Germans' entry into the city, one of the Jewish soldiers learned the following from a Ukrainian woman: "When the Germans appeared in the suburbs of Berdichev, loyal assistants rallied around them.... With great diligence they hunted down Jews, who they discovered in ditches and cellars" (Iakov Ben-Ami, Vremia i pamiat' [Tel Aviv: n.p., 1976], 128).

11 A Writer at War: Vasily Grossman with the Red Army, 1941-1945, ed. and trans. Antony Beevor and Luba Vinogradova (New York: Pantheon Books, 2005), 254.

12 The town's prewar Jewish population numbered 500 (Altshuler, Distribution of the Jewish Population, 22).

13 The city's pre-war Jewish population numbered 15,000 (Ibid., 32). Moisei Loifer, Niti vremeni (Tel Aviv: Israel Press Center, 2000), 108-9.

The town's pre-war Jewish population numbered 900, constituting 39.2 percent of the total population (Altshuler, Distribution of the Jewish Population, 40).

16 Loifer, Niti vremeni, 112.

17 Prior to the war, Gedalia Safian (1920-1985) was a student in the faculty of history at the State University of Belorussia in Minsk. He left Minsk just before the Germans occupied it. After considerable wandering, when he spent some of his nights walking in the dark, he reached the district of Chernigov. There he was inducted into the Red Army, in which he served until November 1945. From November 24, 1944 until his discharge, he kept a diary, in which he would record his thoughts every few days.

On this town, see D. Dombrowska, A. Wein, and A. Weiss, eds., Pinkas ha-kehilot. Polin: entsiklopedyah shel ha-yishuvim ha-Yehudiyim le-min hiyasdam ye- 'ad le-ahar shoat Milhemet ha-'olam ha-sheniyah (The Register of Communities: East Galicia, vol. 2 (Jerusalem: Yad va-shem, 1979-80), 186-87. 
19 "A byl on lish' soldatom," Mishpakha, no. 6 (1999): 94. He writes about a visit to another town: "I took a walk over to that town. What a grim impression it made on me. The center [of the town] where the Jews had lived was in ruins. The houses were still standing but they had no windows or doors-only black holes. Everything had been dragged off. Even the windows had been torn off. All that remained was emptiness and death. The vitality and warmth that were the hallmarks [of these towns] are gone.... Stables have been set up in the synagogues, filth and dirt are everywhere.... I went to the cemetery.... Large, old tombstones dating from the Austro-Hungarian period are still standing.... On some of them our ancestors' pure ideas have been inscribed.... Here the tombstones are broken and potatoes have been planted atop the graves. The dead are not even allowed to rest now. I passed through the town of Lopatin, where 450 [Jewish] families had once lived; not many of them had survived. The houses were destroyed and had been looted. There were two large synagogues: One of them had been converted into a flour mill. How painful it was to see all this! My nation, how cruelly and unjustly has fate treated you!! And for what?"

Ibid. On August 19, 1944, Safian entered the following in his diary: "I came to the town of Turomichi .... The house [where we had taken up quarters] once belonged to the owner of a tavern [by the name of] Fisch, and a physician lived on the second floor. The Germans had shot to death the owner of the house and his tenant together with their families.... The local letter-carrier now threshes his wheat here. The entrance to the house is paved with tombstones from the Jewish cemetery. No matter where I go in this town, I am constantly reminded of the lives that have been snuffed out here."

21 M. Altshuler, I. Arad, and Sh. Krakovskii, eds., Sovetskie evrei pishut Il'e Erenburgu (Jerusalem: Prisma-Press, 1993), 202.

22 Rakhel' Pavlovna Margolina i ee perepiska s Korneem Ivanovichem Chukovskim (Jerusalem: Stav, 1978), 5-10, 55-56.

23 Ber Mark, "Di kvadratne oysies," in Tzum zig: literarisher zamlbukh, ed. P. Markish (Moscow: Der Emes, 1944), 327-32. see my book Yehude Mizrah Kaykaz: toldot ha-Yehudim ha-harariyim me-reshit hamah ha-tessha-esreh (The Jews of the Eastern Caucasus Region: The History of the Caucasus Mountain Jews from the Early $19^{\text {th }}$ Century Onwards) (Jerusalem: Hebrew University, 1989-1990). tion, 20). 
30 I want to thank Dr. Leonid Finberg, who permitted me to use documents from the Institute of Judaica in Kiev-over 100 interviews, which he conducted in the 1990s on the subject "Jewish Life in Ukraine in the Twentieth Century" (henceforth to be referred to as "Judaica"). Testimony of Mania Guralnik, who was born in 1931. (The interviews in "Judaica" are not paginated.)

31 David Kahana, Ahare ha-mabul (Jerusalem: Mossad Harav Kook, 1981), 39. In an interview, Rabbi David Kahana recalled: "There was a victory celebration at the Brandenburg Gate beside the statue of Kaiser Wilhelm. I can't remember whether it took place on May 10 or 20...." On that day, he turned to an officer who referred him to his assistant (denschik), "who was a Communist! He attended party meetings.... Yet he had a warm spot in his heart for any Jew he happened to encounter.... He did everything to provide bread for hungry mouths, to help people leave the village, where Jews had been murdered.... He was constantly risking his life ... He told me [in Yiddish], 'Do you know why I love Jews? My father was an important figure in his beit midrash [house of learning] in Minsk.' ... Suddenly, I saw a group of high-ranking officers ascending ... the stairs. I heard them starting to speak in Yiddish. They said 'Shalom Aleichem'.... One of the members of this group was a general. He was the head of the medical service of a certain brigade, Vovsi [between 1941 and 1947, he was the Red Army's Chief Medical Officer], and we began to converse and toast each other with the Hebrew expression 'L'chaim. We talked in Yiddish and danced. It was clear that he considered Communism to be the only solution for Judaism. Nonetheless, he spoke very fondly of Jews and Judaism! And I saw that he was very happy to see a rabbi in uniform...." (The interview was conducted on July 2, 1963. Oral History Department, Institute of Contemporary Jewry, no. 4/15, 18-19.)

Israel Eichenwald, Bi-derakhim uvi-gevulot (Tel Aviv: Moreshet, 1989), 93.

Ibid., 94.

In his youth, the author, who was born in 1915 or 1916, had distanced himself from anything connected with Judaism and most of his friends were Russians. In 1932, he left his parents and his town, moving to Briansk and then to Leningrad. On the eve of the Second World War, he completed his studies in engineering. In the introduction to his book, the author wrote: "These entries have a documentary character; many of them are engraved in my memory of my distant adolescence and are based on notes that I recorded in the diary I kept when I was on the front" (Ben-Ami, Vremia $i$ pamiat', 125-26).

35 The author is Shimon Cherbinskii, who was born in 1906 and who lived in Kiev until July 1941.

36 Kiev's central boulevard.

37 “Iz pisem," in Babii Iar, 1941-1961, ed. Efraim Baukh ([Israel]: Izdanie Soiuza zemliachestv—vykhodtsev iz SSSR, 1981), 64-65.

38 The soldier was Abram Miropol'skii, who was drafted in 1941 and who received many medals for his courage in battle.

39 On the eve of the war, there were 10,500 Jews in Mariupol' (Altshuler, Distribution of the Jewish Population, 24).

40 L. Miropol'skii, “Kholokost v pamiati odnoi sem'i," Shestye Zaporozhskie evreiskie chteniia (Zaporozh'e, 2002), 74. 
41 On the eve of the war, there were 8,000 Jews in Cherkassy (Altshuler, Distribution of the Jewish Population, 20).

42 Naum Dashevskii, Vospominaniia bez vesti propavshego (Moscow: Moskovskii rabochii, 1990), 217.

43 After his induction into the army, he served as a politruk in a company of riflemen and, in 1943, with the rank of Captain, he was deputy commander of a battalion that was responsible for the political sphere (F. D. Sverdlov, V stroiu otvazhnykh: ocherki o evreiakh-geroiakh Sovetskogo Soiuza [Moscow: A/O “Kniga i biznes", 1992], 285-86). See also Aron Abramovich, $V$ reshaiushchei voine: uchastie i rol' evreev SSSR v voine protiv natsizma, vol. 2 (Tel Aviv: n.p., 1992), 170-71, 533.

44 On the eve of the war, there were one thousand Jews in all the villages in the Tyvrov district, except for the central village (Altshuler, Distribution of the Jewish Population, 48).

Sverdlov, V stroiu otvazhnykh, 285.

Iurii M. Liakhovitskii, Poprannaia mezuza: kniga Drobitskovo Iara: svidetel'stva, fakty, dokumenty o natsistskom genotside evreiskogo naseleniia Khar'kova $v$ period okkupatsii, 1941-1942 (Khar'kov: Osnova, 1991), 94-95.

Iosif Nudel'man, "Evrei na voine," in Nam dorogi eti pozabyt' nel'zia: vospominaniia, stat'i, materialy iz semeinykh arkhivov uchastnikov Velikoi Otechestvennoi voiny 19411945 godov, ed. V. D. Lesev (Jerusalem: n.p., 1995), 173.

On the eve of the war, there were over 25,000 Jews in Nikolaev (Altshuler, Distribution of the Jewish Population, 25).

For these letters, see Yad Vashem Archives, section 075, file 490. (New York: Metropolitan Books, 2006), 289.

54 For a collection of his poems, see Aleksandr Sobolev, Bukhenval'dskii nabat: strokiarestanty (Moscow: EKA, 1996).

Aleksandr Sobolev, Efim Segal, kontuzhennyi serzhant (Moscow: Izdatel'skii dom PIK, 1999), 194.

L. Dubossarskii, V. Gol'dman, A. Peisakhovich, eds. Voiny-evrei vo Vtoroi Mirovoi i 50 let spustia (Tel Aviv: Izd-vo zhurnala Alef, 1995), 196-201.

“Tzveyter plenum fun yidishen antifashistishn komitet in FSSR," Eynikayt, 3 March 1943.

Stalingradskaia epopeia: vpervye publikuemye dokumenty, rassekrechennye FSB RF, ed. Ia. F. Pogonii et al. (Moscow: Zvonnitsa-MG, 2000), 241.

59 Ben-Ami, Vremia i pamiat', 131.

60 "A byl on lish' soldatom," 92.

61 For one such example, see: L. K. Brontman, "Iz dnevnikov voennykh let," Arkhiv evreiskoi istorii, vol. 2 (2005): 82-140. 